\title{
Dynamics of land surface temperature in response to land use land cover change in Phewa watershed, Kaski, Nepal
}

\author{
Sudip Raj Regmi ${ }^{1 *}$, Mahendra Singh Thapa ${ }^{1}$, Rabindra Adhikari ${ }^{1}$ and \\ Raju Raj Regmi ${ }^{1}$ \\ 1 Tribhuvan University, Institute of Forestry, Pokhara
}

\section{KEYWORDS}

Land Use Land Cover Change

Land Surface Temperature

Phewa watershed

Landsat

Supervised

\begin{abstract}
Geospatial tools play an important role in monitoring Land Use Land Cover Change (LULCC) and Land Surface Temperature (LST). This study assessed the extent of LULCC during 1990, 2007 and 2020 using temporal satellite imageries, and estimates LST during the study periods in relation to LULCC and explores various adaptation practices adopted in response to LST change in Phewa watershed. Landsat imageries were used for LULC classification and LST estimation. Purposive household survey $(\mathrm{N}=150)$, key informant survey $(\mathrm{N}=4)$, focus group discussion $(\mathrm{N}=4)$ and direct field observations were carried out to explore various adaptation practices. LULC maps was generated by using supervised classification followed by post classification change detection technique for LULCC analysis. Agricultural land and urban areas were found to have increased by $6.6 \%$ and $0.32 \%$ respectively while forest area, barren land and water bodies were found to have decreased by $1.88 \%, 4.41 \%$ and $0.63 \%$, respectively, between 1990 and 2007. Forest area, urban areas and barren land had increased by $5.54 \%, 1.32 \%$ and $1.48 \%$, respectively, while agricultural land and water bodies were observed to have decreased by $8.2 \%$ and $0.13 \%$, respectively, between 2007 and 2020. The mean LST were $22.59^{\circ} \mathrm{C}, 22.81^{\circ} \mathrm{C}$ and $24.56^{\circ} \mathrm{C}$ in March-April and $14.65^{\circ} \mathrm{C}, 14.97^{\circ} \mathrm{C}$ and $15.27^{\circ} \mathrm{C}$ in January-December, respectively. Urban areas and water bodies exhibit highest and lowest mean values of LST, respectively, during study periods. LULCC due to urban growth and infrastructural developments had contributed to increase in LST. The highest rank to adaptation practices were for changes in cropping patterns and species, followed by agroforestry, use of improved seeds, shift to other income generation activities, use of more fertilizers, irrigation practices and growing vegetables in poly house which were statistically significant. This study provides scientific insights for policy makers and urban planners in improving urban planning and management.
\end{abstract}




\section{Introduction}

Land use is the arrangements, activities and inputs that human undertake on a certain land cover type and the observed bio-physical cover on the earth's surface is land cover (FAO 2000). Land use and land cover change (LULCC) is a modification of the Earth's surface mainly due to anthropogenic activities (Roy et al. 2015) and leads to environmental degradation (Hamad et al. 2018). Ecosystem, arable land, biodiversity, water bodies, greenhouse effects, forestry, ambient climate and soil are adversely affected by LULCC (Vittek et al. 2014). Natural resource management and monitoring of environmental dynamics by assessments of LULCC can contribute to sustainable environmental planning and management (Nayana et al. 2016). Land Surface Temperature (LST) is the skin temperature of surface soilwater content and vegetation cover (Rajendran and Mani 2015); this varies from local to global scale (Li et al. 2013). It is determined by energy fluxes between surface and atmosphere (Voogt and Oke 2003) and this can be applied to climate change modelling and greenhouse effects assessment (Dousset and Gourmelon 2003). It can be used for estimating energy consumption and evaluating heat related risks (Mathew et al. 2016). Evapotranspiration, climate change, hydrological cycle, vegetation monitoring, urban climate and environmental studies are key fields where LST have been widely used (Arnfield 2003). It affects natural and anthropogenic phenomenon (Tran et al. 2017) including agriculture (Smith et al. 2009) and health (Xu et al. 2015). Increase in LST modifies degree of solar radiation's absorption, evaporation rates, desertification, air pollution, albedo, heat storage and wind turbulence (Mallick et al. 2008). Vegetation cover, surface moisture, soil types and topography are the drivers of spatio-temporal LST variation (Osborne and Alvares 2019). LST is one of an important variables which helps in the exchange of earth's surface energy and matter, physical and chemical processes with the atmosphere and is severely affected by LULCC
(Deng et al. 2018). LULCC highly affects LST (Xian and Crane 2005). LST is sensitive to various land surface features and can be used to extract various LULC types' information (Sinha et al. 2015). There is spatial correlation between LST change and LUCCC (Wang et al. 2018) and this can be used for land management and global climate change research. One of the most rapid consequences from the land conversion in an urban area is the development of Urban Heat Island (UHI) which is the variation of LST between the city core area and the peripheral non-urban area (Voogt and Oke 2003). Multi temporal digital satellite imageries help to extract relationship between LST and LULCC which in turn are beneficial for urban land management decision formulation, planning and ecosystem monitoring (Pal and Ziaul 2017).

The analysis of temperature trends for the period 1977 to 1994 reveals a consistent and continuous warming in the period at an annual rate of $0.06^{\circ} \mathrm{C}$ in Nepal (MOE 2010). The General Circulation Models scenario shows that the mean annual temperature to increase by an average of $1.2^{\circ} \mathrm{C}$ by $2030,1.7^{\circ} \mathrm{C}$ by 2050 and $3^{\circ} \mathrm{C}$ by 2100 compared to a pre- 2000 baseline (MOE 2010). Adaptive capacity is the ability of a system to adjust to climate change (including climate variability and extremes) to moderate potential damages to take advantage of opportunities or to cope with the consequences (IPCC 2001). Adaptation strategies exist across local and global scales, from community level responses through local, national and international government interventions (McGray et al. 2007). Adaptation is important in the climate change issue which helps for assessment of impacts and vulnerabilities and development and evaluation of response options (IPCC 2007) and has become a key aspect of scientific and policy making communities (MOE 2010). The ultimate goal of adaptation is to build long term resilience of communities for sustaining their livelihoods even in extreme shocks and stresses.

There was a drastic change in LULC and various drivers play key role for LULCC in 
Phewa watershed (Regmi et al. 2020). Soil erosion, deforestation, unplanned rural road construction and rapid LULCC is mainly degrading Phewa watershed and for sustainable development and management of the watersheds spatial inventories on trends of LULCC are vital (Regmi and Saha 2015). Though LULCC analysis had been done in Phewa watershed for different time periods linking various themes (Bhandari and Darnsawasdi 2014; Paudyal et al. 2017; Regmi and Saha 2015) but the estimation of LST in relation to LULCC is severely lacking in Phewa watershed. So this paper assesses the extent of LULC changes during 1990, 2007 and 2020 using temporal satellite imageries, estimates LST during 1990, 2007 and 2020 in relation to LULCC and explores various adaptation practices adopted in response to LST change in Phewa watershed. Therefore, this paper can help for formulating policies, planning strategies, adaptation plans, information on potential environmental impacts and effective land management for the sustainability of Phewa watershed.

\section{Materials and Methods}

\section{Study Area}

Phewa watershed is located in the south-western part of Kaski district of Gandaki Province which lies in the Chitwan Annapurna Landscape area covering both rural and urban area. It extends between $28^{\circ} 11^{\prime} 39^{\prime \prime}$ North to $28^{\circ} 17^{\prime} 25^{\prime \prime}$ North latitude and $83^{\circ} 47^{\prime} 51^{\prime \prime}$ East to $83^{\circ} 59^{\prime} 17^{\prime \prime}$ East longitude. It possesses moderate subtropical to the cool temperature type of climate. The lower parts of the watershed have a dominance of Sal (Shorea robusta), Katus (Castonopsis indica), Chilaune (Schima wallichii), Tooni (Cedrela toona), Sisoo (Dalbergia sissoo), Pipal (Ficus religiosa), Simal (Bombax ceiba) and Bans (Dendroclamus strictus) etc. and in upper parts, Laligurans (Rhododendron arboreum),

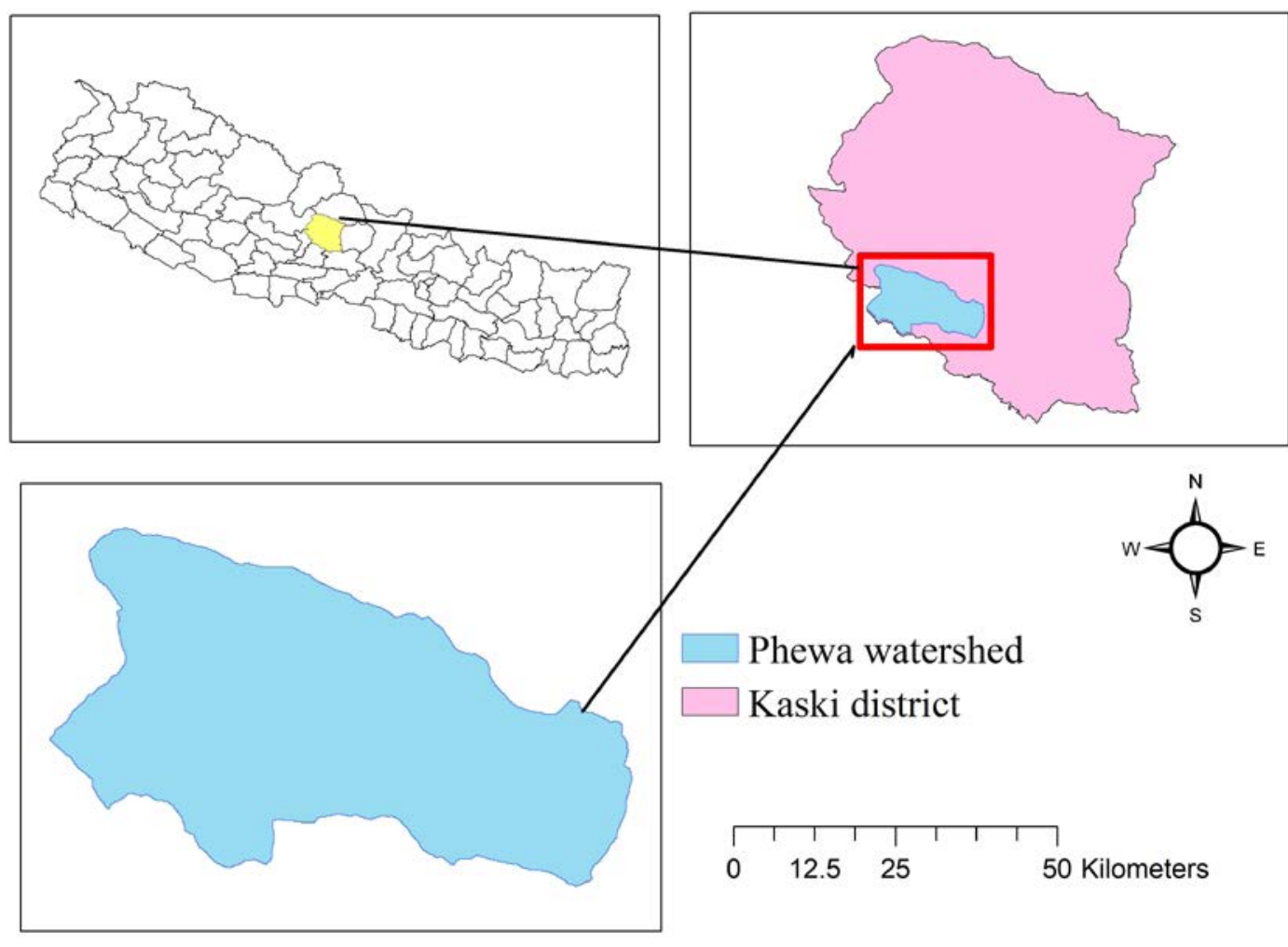

Figure 1: Map of the study area 
Salla (Pinus species), Bamboo (Dendrocalamus species) etc. are the common species (Regmi and Saha 2015). Forest, Agriculture, Bush/Scrub, Waste Land and Built-up Land are the main LULC classes in Phewa watershed. The variation of altitude is from 789-2508.81 m above msl (Regmi and Saha 2015) in the west at Panchase which is biologically rich geographical area and the highest summit of the watershed area.

\section{Data collection}

The primary data related to the various adaptation practices adopted in response to LST change were collected through direct field observation, purposive household survey $(\mathrm{N}=150)$, key informant interviews $(\mathrm{N}=4)$ and focus group discussions $(\mathrm{N}=4)$ while the secondary data viz Landsat TM for 1990, Landsat TM for 2007 and Landsat OLI_TIRS for 2020 imageries were freely downloaded from USGS website (earthexplorer.usgs.gov). Aster DEM from USGS website (earthexplorer.usgs. gov) was used for boundary demarcation of the watershed. Temperature data from
1990 to 2020 was collected from nearby meteorological station to estimate the trend and variability of temperature in study area. Methods

\section{LULC Analysis}

Radiometric, Atmospheric and Sun angle corrections of respective Landsat imageries were carried out. LULC maps for change detection analysis were generated using supervised classification with maximum likelihood classifier (Lillesand et al. 2004). Digital supervised classification of Landsat TM for 1990, 2007 and OLI_TIRS for 2020 imageries was analyzed for assessment of LULCC. The LULC classes used for the classification were forest, agricultural land, barren land, water bodies and urban areas (Table 2).

\section{Land Surface Temperature Retrieval for the study time periods (Haylemariyam 2018) \\ (a) Conversion of pixel values to radiance from metadata of imageries: \\ For Landsat TM 1990 and 2007 for band 6}

Table 1: Data specification of satellite imageries used in LULC classification

\begin{tabular}{lccccccc}
\hline Satellite & Sensor ID & Path/row & $\begin{array}{c}\text { Total } \\
\text { bands }\end{array}$ & $\begin{array}{c}\text { Temporal } \\
\text { resolution }\end{array}$ & $\begin{array}{c}\text { Spatial } \\
\text { resolution }(\mathbf{m})\end{array}$ & $\begin{array}{c}\text { PAN } \\
\text { Band }\end{array}$ & $\begin{array}{c}\text { Date of } \\
\text { acquisition }\end{array}$ \\
\hline Landsat 5 & TM & $142 / 40$ & $1-7$ & 16 days & 30.30 & Nil & $1990-04-16$ \\
Landsat 5 & TM & $142 / 40$ & $1-7$ & 16 days & 30.30 & Nil & $2007-03-30$ \\
Landsat 8 & OL1_TIRS & $142 / 40$ & $1-11$ & 16 days & 30.30 & $15: 10-8$ & $2020-04-02$ \\
Landsat 5 & TM & $142 / 40$ & $1-7$ & 16 days & 30.30 & Nil & $1990-01-26$ \\
Landsat 5 & TM & $142 / 40$ & $1-7$ & 16 days & 30.30 & Nil & $2007-01-25$ \\
Landsat 8 & OL1_TIRS & $142 / 40$ & $1-11$ & 16 days & 30.30 & $15 \mathrm{~m}, \mathrm{~B}-8$ & $2020-12-14$ \\
\hline
\end{tabular}

Table 2: LULC classes used for classification

\begin{tabular}{|c|c|c|}
\hline S. N. & LULC types & Descrption \\
\hline 1. & Forest & Shrubs land, trees, grassland bushes. \\
\hline 2. & Agricultural land & $\begin{array}{l}\text { Cultivation in sloping mountainous areas in terraced fields In the } \\
\text { downstream of study area, mainly variety of paddy is growing and } \\
\text { irrigation is good. }\end{array}$ \\
\hline 3. & Barren land & $\begin{array}{l}\text { Sandy areas, Areas exposed after landslides, flash floods and soil } \\
\text { erosion. Quality of soil is poor. }\end{array}$ \\
\hline 4. & Urban areas & Urban and rural human settlement areas. \\
\hline 5. & Water bodies & Lake and rivers with clear water \\
\hline
\end{tabular}


(spatial resolution $120 \mathrm{~m}$ ).

$\mathrm{L} \lambda=\left(\frac{\operatorname{Lmax} \lambda-\operatorname{Lmin} \lambda}{\mathrm{Qcalmax}-\mathrm{Qcalmin}}\right) *(\mathrm{Qcal}-\mathrm{Qcalmin})+\mathrm{Lmin} \lambda$ Where,

$\mathrm{L} \lambda=$ Spectral Radiance at the sensor's aperture in watts/ (meter squared $\times$ ster $\times \mu \mathrm{m}$ )

$\mathrm{Lmax} \lambda=$ the spectral radiance that is scaled to QCALMAX in watts/ (meter squared $\times$ ster $\times$ $\mu \mathrm{m})(15.303)$

$\operatorname{Lmin} \lambda=$ the spectral radiance that is scaled to QCALMIN in watts/ (meter squared $\times$ ster $\times$ $\mu \mathrm{m})$ (1.238)

Qcalmax =the maximum quantized calibrated pixel value (corresponding to $\operatorname{Lmax} \lambda$ ) in $\mathrm{DN}$ (255)

Qcalmin=the minimum quantized calibrated pixel value (corresponding to $\operatorname{Lmin} \lambda$ ) in $\mathrm{DN}$ (1) Qcal=the quantized calibrated pixel value in DN

For Landsat OLI_TIRS 2020 for band 10

Band 11 is not recommended for LST retrieval because of larger calibration uncertainty (USGS 2014). The LST estimated from Band 10 (spatial resolution $100 \mathrm{~m}$ ) (with weaker absorption) has higher accuracy than Band 11 (Yu et al. 2014).

$\mathrm{L} \lambda=\mathrm{ML}^{\star} \mathrm{Qcal}+\mathrm{AL}$

$\mathrm{L} \lambda=$ TOA spectral radiance (Watts/ $\left(\mathrm{m}^{2} \times \mathrm{srad}\right.$ $\times \mu \mathrm{m})$ ),

$\mathrm{ML}=$ Band-specific multiplicative rescaling factor from the metadata (RADIANCE MULT_BAND_x, where $\mathrm{x}$ is the band number) (0.0003342)

$\mathrm{AL}=\mathrm{Band}$-specific additive rescaling factor from the metadata (RADIANCE_ADD_ BAND_x, where $\mathrm{x}$ is the band number) (0.1) Qcal=Quantized and calibrated standard product pixel values (DN).

(b) Conversion of radiance to At-Satellite temperature from metadata of imageries:

$$
T=\frac{K 2}{\ln \left(\frac{K 1}{L \lambda}+1\right)}-273.15
$$

$\mathrm{T}=\mathrm{Top}$ of atmosphere brightness temperature in degree $\left({ }^{\circ} \mathrm{C}\right)$

$\mathrm{K} 2=$ Band specific thermal conversion constant from metadata from metadata $\left(\mathrm{K}_{2}\right.$ CONSTANT_BAND_x, where $\mathrm{x}$ is the thermal band number) (1260.56 for TM sensor and 1321.08 for OLI_TIRS sensor)

$\mathrm{K} 1=\mathrm{Band}$ specific thermal conversion constant from metadata from metadata $\left(\mathrm{K}{ }_{-}\right.$ CONSTANT_BAND_x, where $\mathrm{x}$ is the thermal band number) (607.76 for TM sensor and 774.885 for OLI_TIRS sensor)

$\mathrm{L} \lambda=$ Spectral radiance in watts/ (meter squared $\times$ ster $\times \mu \mathrm{m}$ ).

(c) Normalized difference vegetation index calculation:

For Landsat 5 TM, NDVI=(Band4-Band3)/ (Band4+Band3)

Band 4 is Near infrared and Band 3 is Red

For Landsat 8 OLI/TIRS, NDVI=(Band 5-Band 4)/(Band 5+Band4)

Band 5 is Near infrared and Band 4 is Red

(d) Retrieving of land surface emissivity $\mathrm{e}=0.004 \mathrm{PV}+0.986$

Where, $\mathrm{e}=$ Land surface emissivity

$\mathrm{PV}=$ Proportion of vegetation

$\mathrm{PV}=(($ NDVI - NDVImin $)) /($ NDVImax NDVImin) $)^{2}$

NDVI min=minimum value of NDVI

NDVI $\max =$ minimum value of NDVI

(e) Land surface temperature (LST)

$$
L S T=B T /\left(1+\frac{\lambda B T}{p}\right) * \ln (e)
$$

$\mathrm{BT}=$ at satellite temperature

$\lambda=$ wavelength of emitted radiance for band 6 for Landsat TM $5(11.45 \mu \mathrm{m})$ and band 10 for Landsat OLI_TIRS $(10.8 \mu \mathrm{m})$

$\mathrm{p}=\mathrm{hc} / \mathrm{s}$

$\mathrm{h}=$ Planck's constant $\left(6.626^{\star} 10^{-34} \mathrm{JS}\right)$

$\mathrm{s}=$ Boltzmann constant $\left(1.38^{\star} 10^{-23} \mathrm{~J} / \mathrm{K}\right)$

$\mathrm{c}=$ Velocity of light $\left(2.998^{\star} 10^{8} \mathrm{~m} / \mathrm{s}\right)$

$\mathrm{p}=14380 \mathrm{mK}$

$\mathrm{e}=$ Land surface emissivity

\section{Data Processing and Analysis}

LULC classification and LULCC analysis for study periods were performed. Finally, 


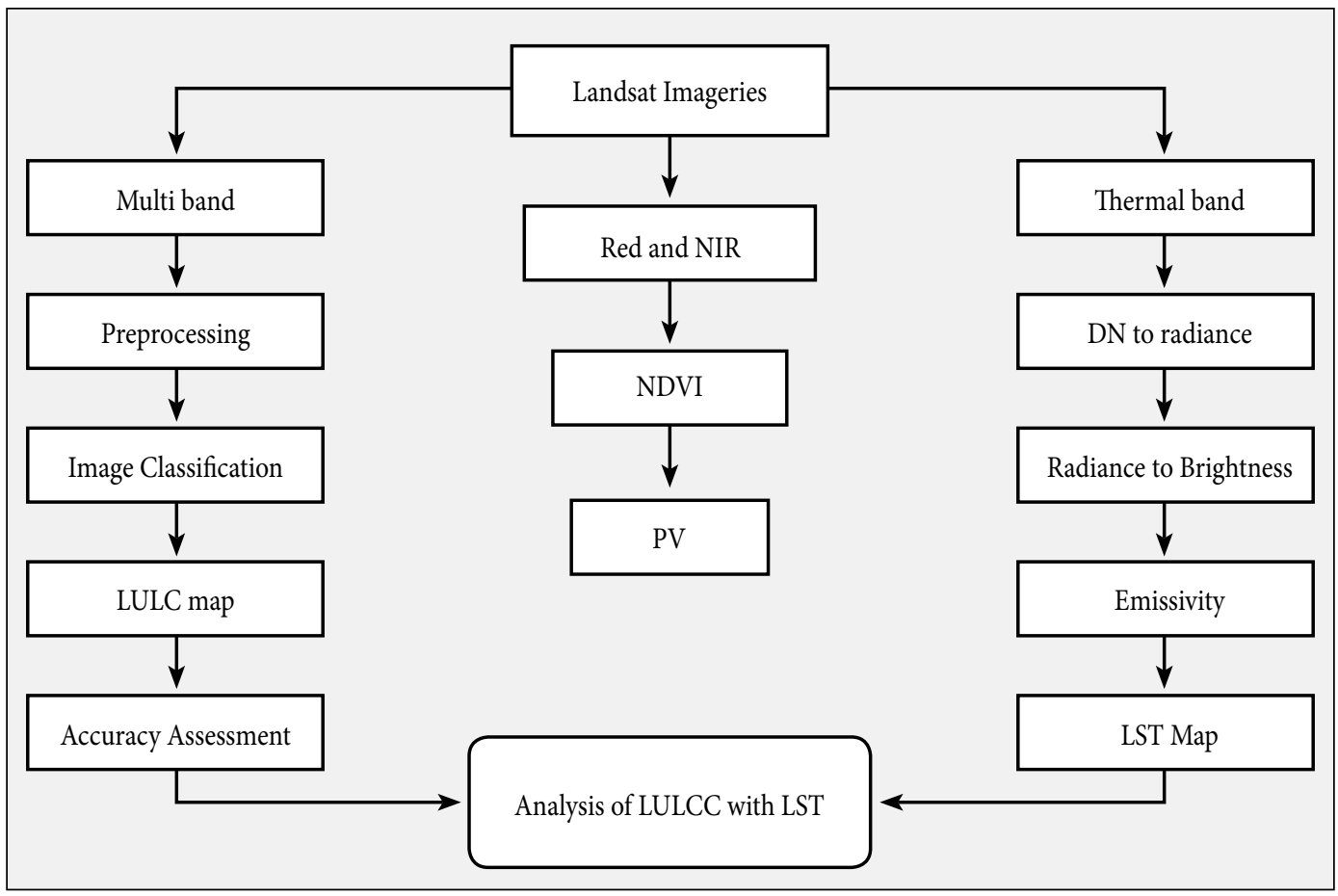

Figure 2: General work flow of methodology

Change/No Change Matrix was computed. LST maps of band 6 for 1990 and 2007 and LST map of band 10 for 2020 were generated with the help of metadata from respective Landsat imageries. Create random points tool was used to lay out random points in the study area. Mean temperature was found for study periods of each LULC classes and LULCC classes in the study area by using create random points maps, LST maps, LULC maps and respective change/no change map. All these analyses were performed in ArcMap 10.3.

Data of temperature from 1990 to 2020 was obtained from Office of Hydrology and Meteorology, Pokhara. The trends of temporal variation of temperature were analyzed using linear regression. The linear trend between time series and temperature data are as given in equation below.

$\mathrm{y}=\mathrm{a}+\mathrm{bx}$ (Fig. 6)

Where, $y=$ temperature, $x=$ time (year), "a" and "b" are constants

Prioritized responses of respondents on various adaptation practices adopted in response to LST change in the watershed were analyzed through mean rank and non-parametric Friedman's rank test in SPSS 23 which was used in (Bhatta et al. 2018) to analyze people's perception based on rank.

\section{Results}

\section{LULC Dynamics of 1990, 2007 and 2020}

The LULC maps for study periods is shown in Fig. 3 (A), (B) and (C). There were drastic changes in LULC during these periods in the watershed. In 1990, forest covered 4853.97 ha (40.49\%) followed by agricultural land which covered 4579.83 ha (38.20\%). Barren land, urban areas and water bodies covered 1236.60 ha $(10.31 \%), 805.77$ ha $(6.72 \%)$ and 513.36 ha (4.28\%), respectively. In 2007, agricultural land covered an area of 5371.29 ha (44.80\%) followed by forest which covered 4628.97 ha (38.61\%). Urban areas, barren land and water bodies covered 843.48 ha $(7.04 \%), 707.76$ ha $(5.90 \%)$ and 438.03 ha $(3.65 \%)$, respectively. In 2020 , 


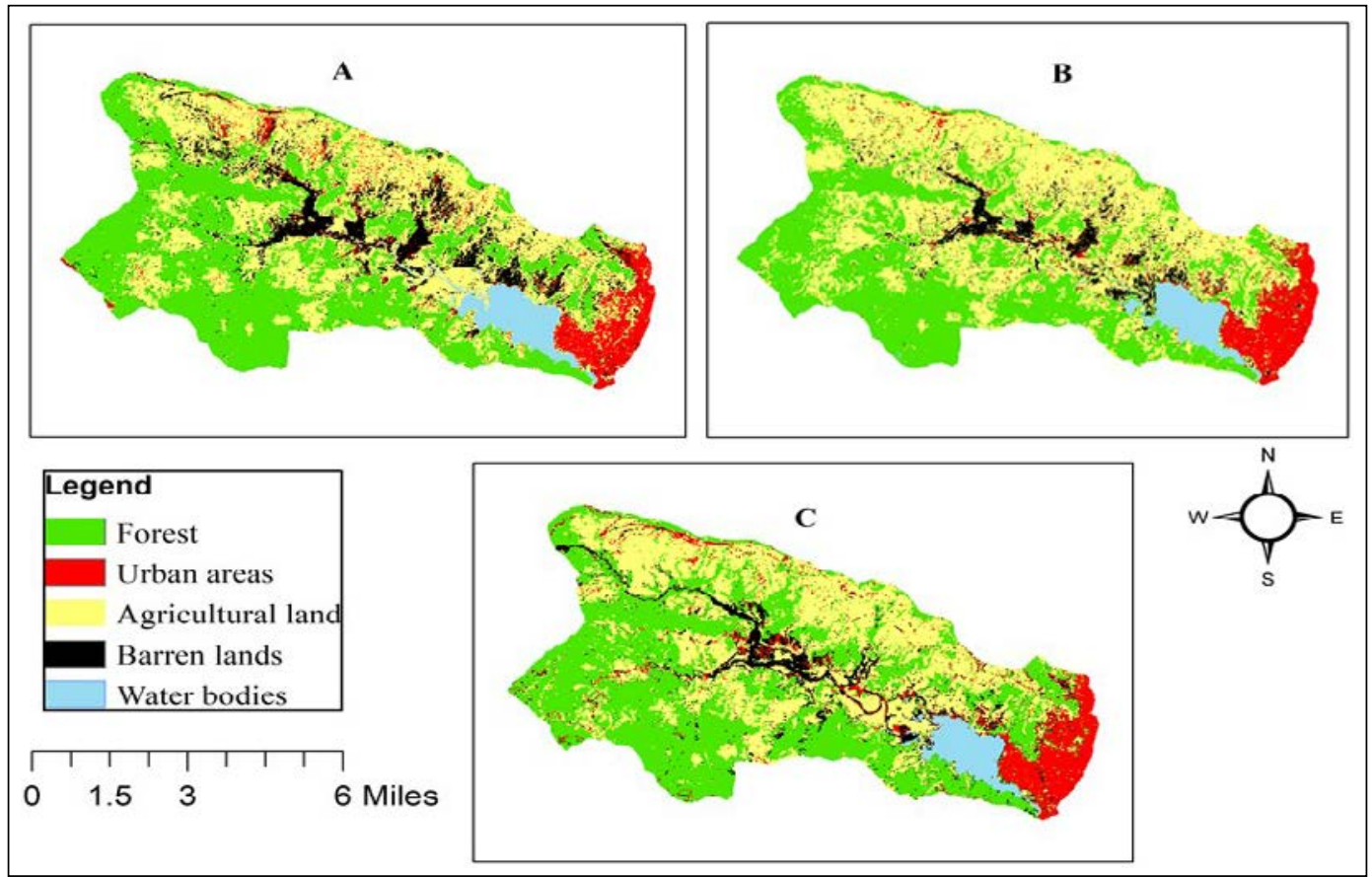

Figure 3: LULC map for (A) 1990, (B) 2007 and (C) 2020

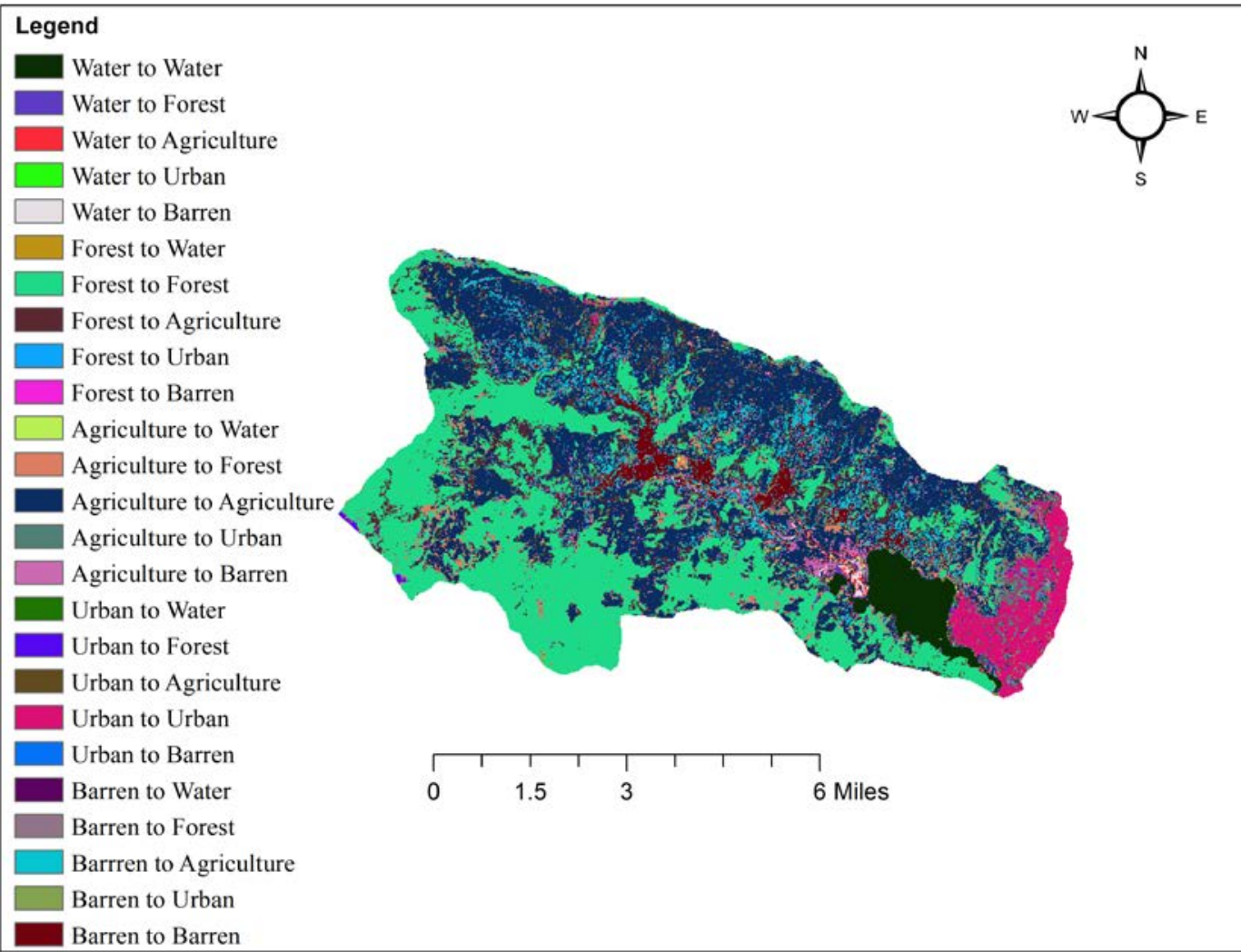

Figure 4: Change/No change map during 1990 to 2007 
forest covered 5292.99 ha $(44.15 \%)$ followed by agricultural land which covered 4387.59 ha (36.60\%). Urban areas, barren land and water bodies covered 1002.06 ha $(8.36 \%), 884.52$ ha $(7.38 \%)$ and 422.37 ha $(3.52 \%)$, respectively.

\section{Accuracy Assessment}

Altogether 160 ground truth positions were collected with the help of Google Earth image for 1990 and 2007. Additional GPS points combined with Google Earth image were utilized to collect ground truth positions of classified LULC map for 2020. Confusion matrix was used for accuracy assessment. The overall accuracy of the classified maps was $85.63 \%, 88.75 \%$ and $90.63 \%$, respectively. The Kappa coefficients were $0.81,0.84$ and 0.87 , respectively.

Table 3: Change/no change matrix during 1990 and 2007

\begin{tabular}{lcccccc}
\hline Years 1990/2007 & Forest & $\begin{array}{c}\text { Urban } \\
\text { areas }\end{array}$ & $\begin{array}{c}\text { Barren } \\
\text { land }\end{array}$ & $\begin{array}{c}\text { Water } \\
\text { bodies }\end{array}$ & $\begin{array}{c}\text { Agricultural } \\
\text { land }\end{array}$ & $\begin{array}{c}\text { Total area } \\
\text { in 1990\% }\end{array}$ \\
\hline Forest & $33.60^{\star}$ & 0.12 & 0.12 & 0.04 & 6.59 & 40.49 \\
Urban areas & 0.28 & $4.5^{\star}$ & 0.26 & 0.002 & 1.68 & 6.72 \\
Barren land & 0.59 & 0.72 & $3.30^{\star}$ & 0.01 & 5.71 & 10.31 \\
Water bodies & 0.25 & 0.05 & 0.2 & $3.52^{\star}$ & 0.26 & 4.28 \\
Agricultural aland & 3.89 & 1.64 & 2.01 & 0.09 & $30.56^{\star}$ & 38.2 \\
Total area in 2007\% & 38.61 & 7.04 & 5.9 & 3.65 & 44.8 & 100 \\
\hline
\end{tabular}

NOTE: ‘` represents the no change in area of specific LULC used.

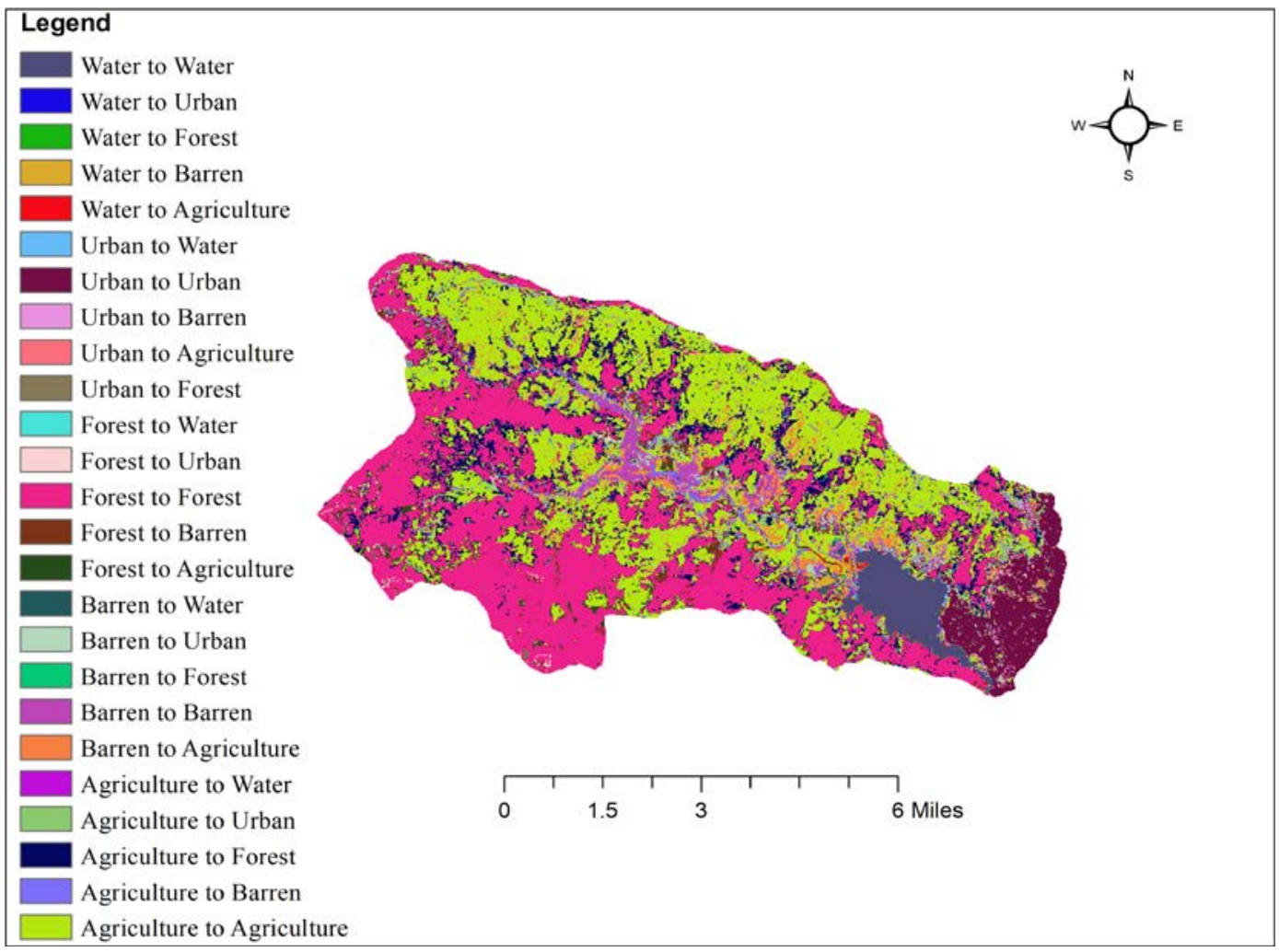

Figure 5: Change/No change map during 2007 to 2020 
As shown in change/no change map for 19902007 is shown in (Fig. 4) land use was changed from forest to agricultural land by $6.59 \%$, barren land to agricultural land by $5.71 \%$, agricultural land to forest by $3.89 \%$, urban areas to agricultural land by $1.68 \%$ and water bodies to agricultural land by $0.26 \%$ (Table 3 ).

The change/no change map for 2007-2020 (Fig. 5) shows that the land use was changed from agricultural land to forest by $9.77 \%$, forest area to agricultural land by $2.52 \%$, barren land to agricultural land by $3.27 \%$, urban areas to agricultural land by $0.93 \%$ and water bodies to barren land by $0.15 \%$ (Table 4).

\section{Temperature variability meteorological station \\ from}

The meteorological data showed variability in the temperature trend (Fig. 6) and is in increasing trend for both maximum and minimum temperature in average annually.

\section{Analysis of LST}

The LST map extracted from the thermal infrared band of Landsat data for March and April in 1990, 2007 and 2020 is shown in Fig. 7. The details of LST information are shown in Table 5.

Table 4: Change/no change matrix during 2007 and 2020

\begin{tabular}{lcccccc}
\hline Years 2007/2020 & Forest & $\begin{array}{c}\text { Urban } \\
\text { areas }\end{array}$ & $\begin{array}{c}\text { Barren } \\
\text { land }\end{array}$ & $\begin{array}{c}\text { Water } \\
\text { bodies }\end{array}$ & $\begin{array}{c}\text { Agricultural } \\
\text { land }\end{array}$ & $\begin{array}{c}\text { Total area } \\
\text { in 2007\% }\end{array}$ \\
\hline Forest & $33.68^{*}$ & 0.61 & 1.8 & 0.1 & 5.59 & 38.61 \\
Urban areas & 0.37 & $5.20^{\star}$ & 0.52 & 0.02 & 0.93 & 7.04 \\
Barren land & 0.24 & 0.42 & $1.93^{\star}$ & 0.04 & 3.27 & 5.9 \\
Water bodies & 0.08 & 0.02 & 0.15 & $3.30^{\star}$ & 0.1 & 3.65 \\
Agricultural aland & 9.77 & 2.11 & 2.97 & 0.07 & $29.88^{\star}$ & 44.8 \\
Total area in 2020\% & 44.15 & 8.36 & 7.38 & 3.52 & 36.6 & 100 \\
\hline
\end{tabular}

NOTE: (*) represents the no change in area of specific LULC used.

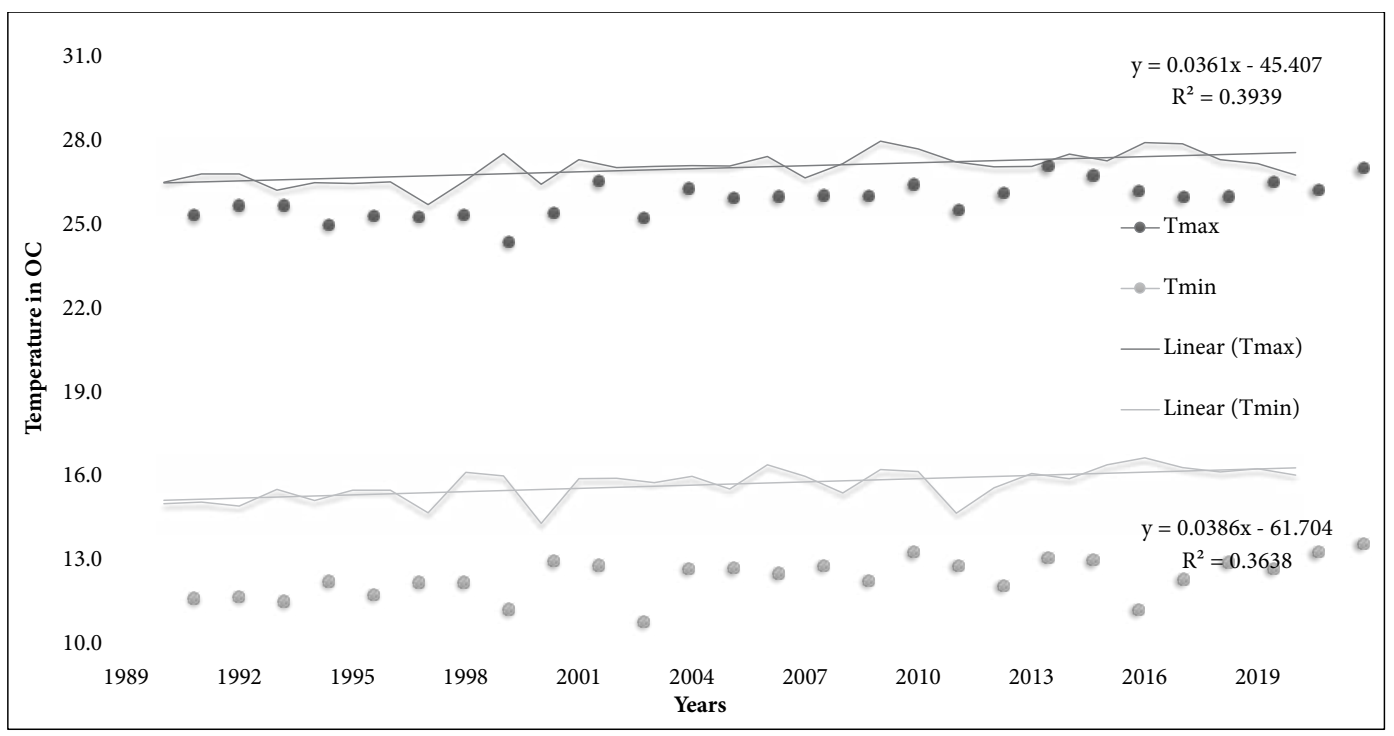

Figure 6: Average annual maximum and minimum temperature trend 


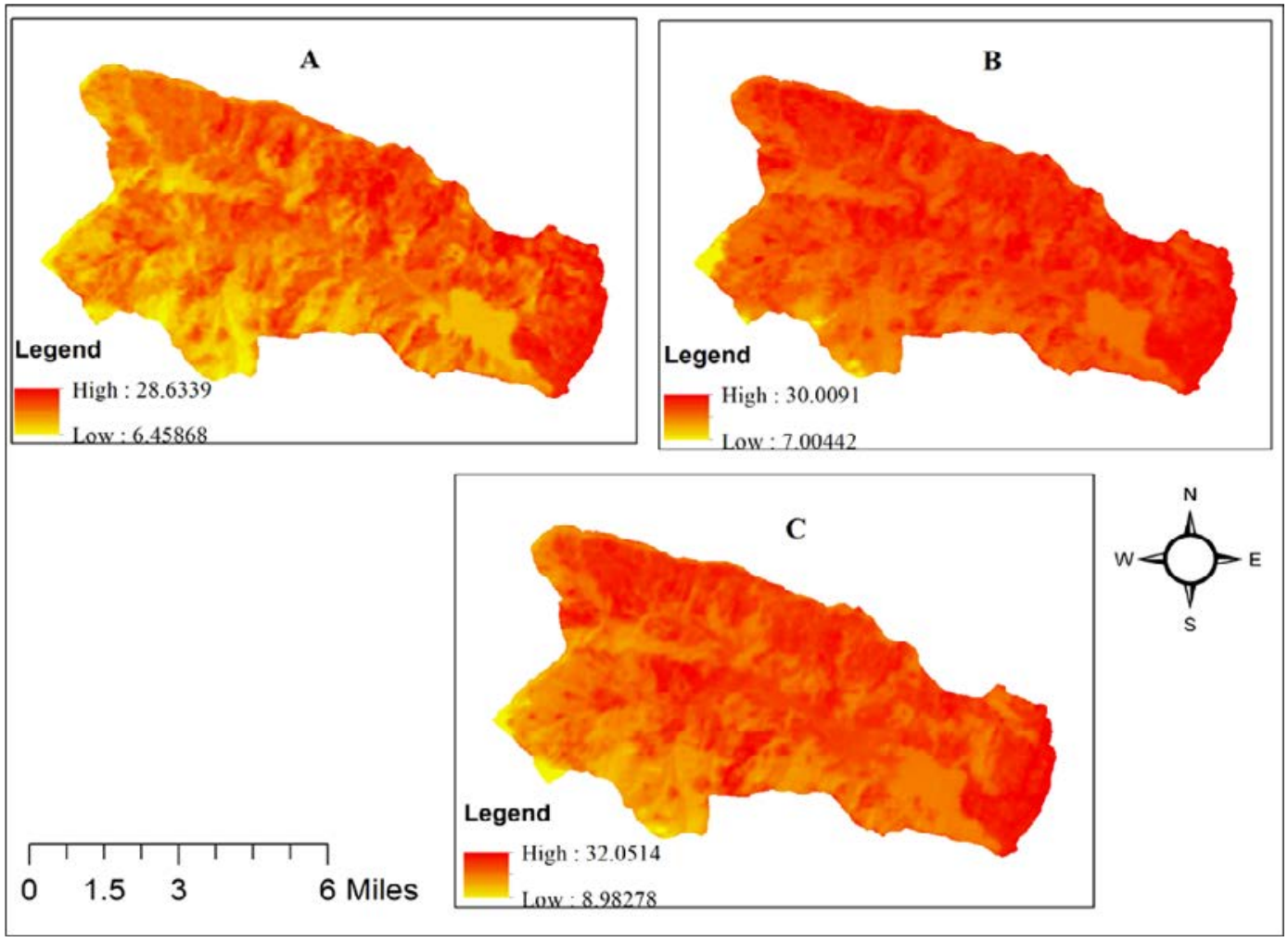

Figure 7: LST map for (A) 1990, (B) 2007 and (C) 2020

The LST map extracted from the thermal infrared band of Landsat data for January and December in 1990, 2007 and 2020 is shown in Fig. 8. The details of LST information are shown in Table 5.

As shown in Table 5, the mean LST values fluctuate between 1990, 2007 and 2020 for March-April and January-December. The mean LST increased by $0.22^{\circ} \mathrm{C}$ from 1990 to 2007 and by $1.75^{\circ} \mathrm{C}$ from 2007 and 2020 in March-April. During 30 years from 1990 to 2020 mean LST was increased by $1.97^{\circ} \mathrm{C}$.

The mean LST increased by $0.35^{\circ} \mathrm{C}$ from 1990 to 2007 and by $0.30^{\circ} \mathrm{C}$ from 2007 and 2020 in January-December. During 30 years from 1990 to 2020 mean LST was increased by $0.62^{\circ} \mathrm{C}$. There was overall increasing trend of mean LST for March-April and January-December for study periods in Phewa watershed.
From the analysis of this study, the relationship between LULC and LST we observed that the mean LST of urban areas was highest and water bodies was lowest than other LULC classes over the study periods for March-April and JanuaryDecember. The details of mean LST in LULC classes for March-April and January-December is shown in (Table 6).

\section{LST change in different detected LULCC categories}

The analysis of change/no change map and respective LST maps for March-April and JanuaryDecember was conducted. The results shows that if one LULC class is changed to urban areas there will be more temperature in that newly grown land than if LULC class is changed to forest areas. The details of newly grown land with respective mean LST information for study periods in March-April and January-December is shown below (Table 7). 


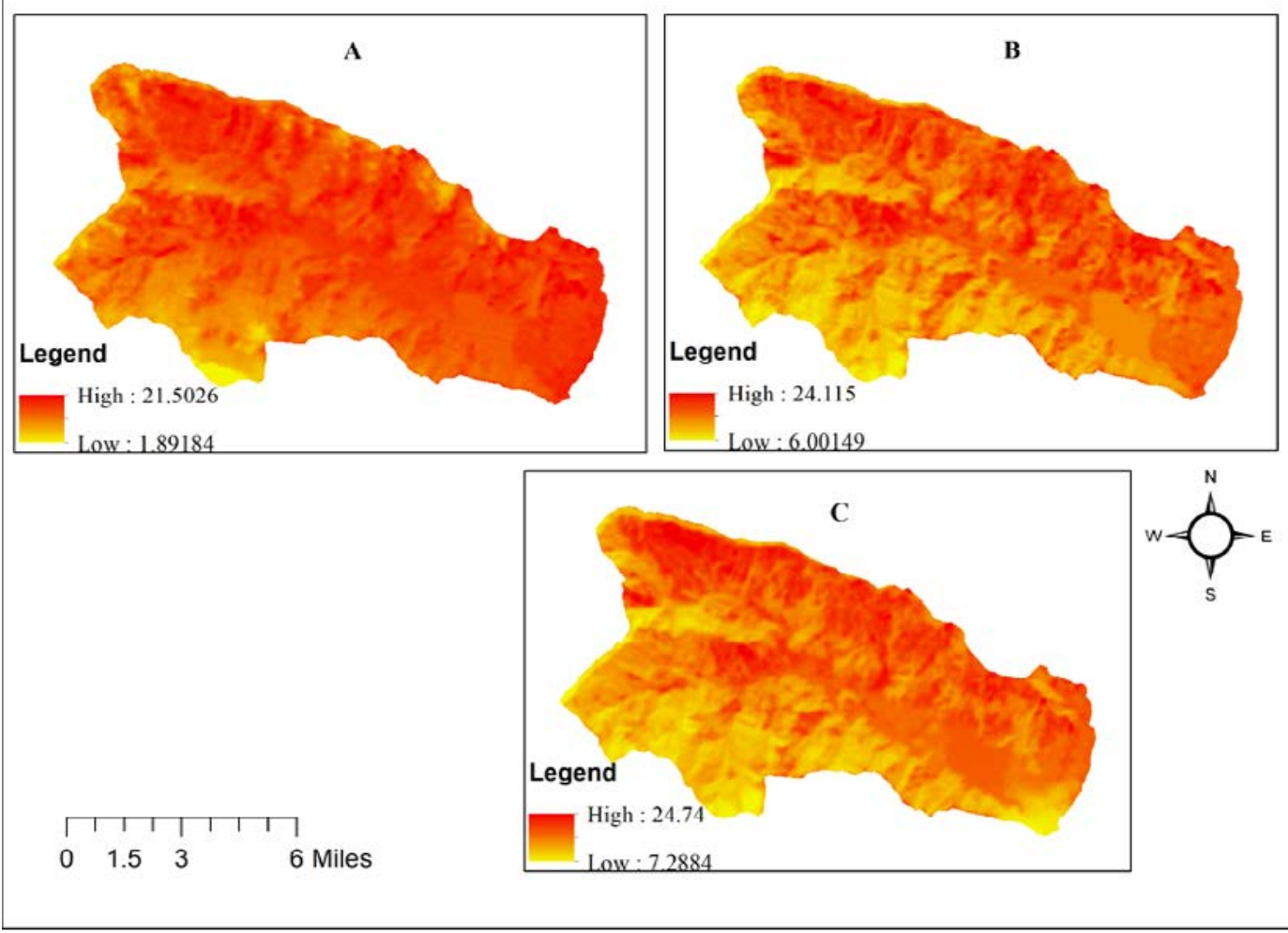

Figure 8: LST map for (A) 1990, (B) 2007 and (C) 2020

Variation of mean LST with reference to altitudinal range for March-April and January-December in Phewa watershed

From Aster DEM, extract by mask was tool was used to extract area of interest.The highest elevation of Phewa watershed was $2418.1 \mathrm{~m}$ and lowest elevation was $759.156 \mathrm{~m}$ with a mean elevation as $1203.65 \mathrm{~m}$ (Fig. 9A).

Three altitudinal zone as Tropical zone (below $1000 \mathrm{~m})$, Subtropical zone $(1000-2000 \mathrm{~m})$ and Temperate zone (above $2000 \mathrm{~m}$ ) (Fig. 9B). The mean LST was found to be increased in study periods in all altitudinal zone (Table 8).

\section{Socio-economic characteristics of respondents}

Among the surveyed 150 households, female represented $53.30 \%$ and male $46.70 \%$. Old (above 50 ) age category represented $66.70 \%$ followed by adult (36-49) $21.30 \%$ and young (18-35) $12 \%$. Brahmin/Chettri was dominant ethnicity with $76.70 \%$, followed by Janajati $15.30 \%$ and Dalit by $8 \%$. In education status of the respondents,

Table 5: Statistics of LST for study periods

\begin{tabular}{ccccc}
\hline Years & Months & Minimum LST ${ }^{\mathbf{0}} \mathbf{C}$ & Maximum LST $^{\mathbf{0}} \mathbf{C}$ & Mean $^{\text {LST }}{ }^{\mathbf{0}} \mathbf{C}$ \\
\hline 1990 & April & 6.45 & 28.63 & 22.59 \\
1990 & January & 1.81 & 21.5 & 14.65 \\
2007 & March & 7.01 & 30.01 & 22.81 \\
2007 & January & 6.01 & 24.11 & 14.97 \\
2020 & April & 8.98 & 32.05 & 24.56 \\
2020 & December & 7.28 & 24.74 & 15.27 \\
\hline
\end{tabular}


Table 6: Mean LST of each LULC classes in study periods for March-April and January-December

\begin{tabular}{clcc}
\hline Years & LULC Classes & Mean LST ${ }^{\mathbf{0}}$ C in March-April & Mean LST $^{\mathbf{0}}$ C in Jan-Dec \\
\hline \multirow{3}{*}{1990} & Forest & 20.78 & 15.38 \\
& Agricultural land & 23.71 & 16.62 \\
& Urban areas & 25.3 & 17.85 \\
& Water bodies & 20.17 & 14.7 \\
& Barren land & 23.49 & 16.32 \\
& Forest & 21.03 & 15.98 \\
& Agricultural land & 24.9 & 17.95 \\
& Urban areas & 25.86 & 18.02 \\
& Water bodies & 20.87 & 14.91 \\
& Barren land & 24.27 & 16.97 \\
& Forest & 23.3 & 16.42 \\
& Agricultural land & 25.7 & 18.07 \\
& Urban areas & 28.83 & 18.74 \\
& Water bodies & 21.18 & 16.38 \\
& Barren land & 24.86 & 17.76 \\
\hline
\end{tabular}

Table 7: Mean LST OC in various transformed LULC classes in March-April and January-December:

\begin{tabular}{lcccccc}
\hline \multirow{2}{*}{\multicolumn{1}{c}{ Newly grown land }} & \multicolumn{3}{c}{ March-April } & \multicolumn{3}{c}{ January-December } \\
\cline { 2 - 7 } & 1990 & 2007 & 2020 & 1990 & 2007 & 2020 \\
\cline { 3 - 7 } Water bodies to Forest & 21.52 & 22.42 & 22.81 & 13.61 & 14.36 & 15.11 \\
Water bodies to Agricultural land & 22.29 & 23.68 & 24.11 & 15.17 & 15.79 & 16.09 \\
Forest to Agricultural land & 23.52 & 23.70 & 23.93 & 14.24 & 15.11 & 15.54 \\
Forest to Barren land & 21.25 & 22.18 & 23.15 & 12.36 & 14.39 & 14.41 \\
Agricultural land to Forest & 22.21 & 23.24 & 24.82 & 14.22 & 15.21 & 15.87 \\
Agricultural land to Urban areas & 24.22 & 25.68 & 26.11 & 16.38 & 17.10 & 18.24 \\
Agricultural land to Barren land & 23.92 & 24.43 & 25.74 & 16.13 & 16.58 & 17.01 \\
Urban areas to Forest & 22.87 & 24.54 & 25.07 & 15.36 & 16.92 & 18.36 \\
Urban areas to Agricultural land & 24.68 & 24.79 & 25.67 & 15.67 & 16.86 & 17.67 \\
Urban areas to Barren land & 22.87 & 24.97 & 25.76 & 15.28 & 16.10 & 17.07 \\
Barren land to Forest & 22.08 & 22.90 & 23.24 & 14.08 & 15.01 & 15.60 \\
Barren land to Agricultural land & 23.93 & 24.30 & 26.07 & 16.31 & 17.34 & 17.70 \\
Barren land to Urban areas & 23.95 & 24.49 & 26.09 & 16.15 & 17.06 & 17.41 \\
\hline
\end{tabular}

illiterate was dominant by $66.70 \%$. Within the literate category of $33.30 \%$, secondary education (9-12) represented $16.70 \%$ followed by primary education (1-8) $11.30 \%$ and Bachelor level by $5.30 \%$. Agricultural occupation was dominant among the respondents which represented $71.30 \%$, followed by business $11.30 \%$, wage labor $6.70 \%$, abroad $4.70 \%$, study $3.30 \%$ and government/private service by $2.70 \%$.

The Table 9 deals with various adaptation practices in response to LST change in Phewa watershed felt by the respondents. The highest rank to adaptation practices was for change 


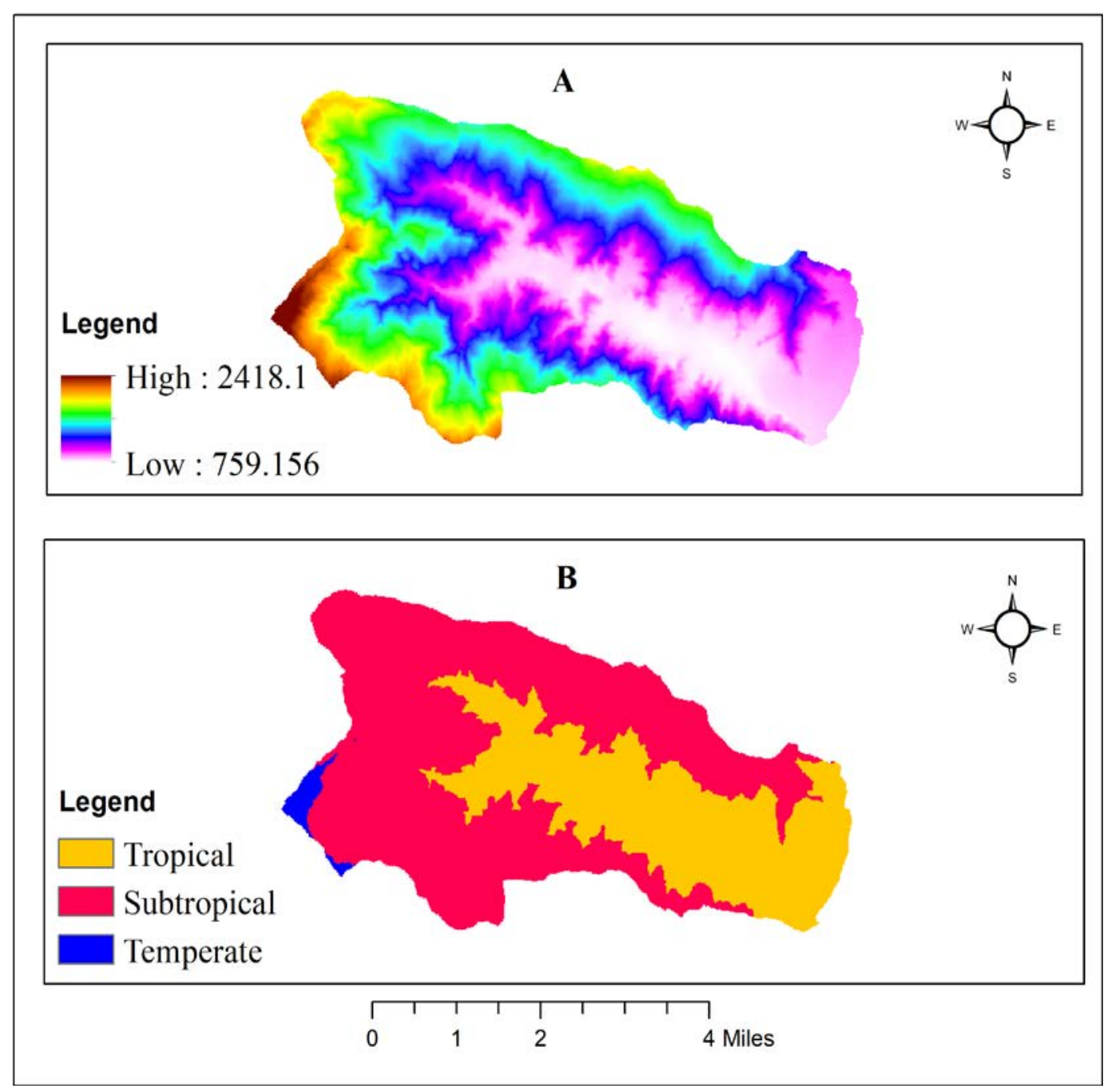

Figure 9: DEM of Phewa watershed (A) and (B) Different altitudinal zone

Table 8: Mean LST in different altitudinal range for March-April and January-December

\begin{tabular}{clccc}
\hline Years & \multicolumn{1}{c}{ Months } & $\begin{array}{c}\text { Means LST }{ }^{\circ} \mathrm{C} \text { in } \\
\text { tropical zone }\end{array}$ & $\begin{array}{c}\text { Means LST }{ }^{\circ} \mathrm{C} \text { in } \\
\text { sub-tropical zone }\end{array}$ & $\begin{array}{c}\text { Means LST }{ }^{\circ} \mathrm{C} \text { in } \\
\text { temperature zone }\end{array}$ \\
\hline 1990 & April & $24.02^{\circ} \mathrm{C}$ & $22.08^{\circ} \mathrm{C}$ & $13.19^{\circ} \mathrm{C}$ \\
1990 & January & $15.39^{\circ} \mathrm{C}$ & $13.89^{\circ} \mathrm{C}$ & $9.6^{\circ} \mathrm{C}$ \\
2007 & March & $24.51^{\circ} \mathrm{C}$ & $23.35^{\circ} \mathrm{C}$ & $14.13^{\circ} \mathrm{C}$ \\
2007 & January & $15.75^{\circ} \mathrm{C}$ & $14.74^{\circ} \mathrm{C}$ & $10.45^{\circ} \mathrm{C}$ \\
2020 & April & $25.64^{\circ} \mathrm{C}$ & $24.43^{\circ} \mathrm{C}$ & $18.17^{\circ} \mathrm{C}$ \\
2020 & December & $17.46^{\circ} \mathrm{C}$ & $16.71^{\circ} \mathrm{C}$ & $12.3^{\circ} \mathrm{C}$ \\
\hline
\end{tabular}


Table 9: Friedman test on rank to various adaptation practices in response to LST change

\begin{tabular}{lcc}
\hline \multicolumn{2}{c}{ Number of respondents $\mathbf{n = 1 5 0}$ with $\mathbf{~} \mathbf{f}=\mathbf{6}$} \\
\hline \multicolumn{1}{c}{ Adaptation practices } & Mean Rank & Friedman Chi square value (p value) \\
\hline Change in cropping patterns and species & $3.61(1)$ \\
Improved/Hybrid seeds & $3.72(3)$ \\
Agroforestry & $3.62(2)$ \\
Shift to other Income Generation activities & $3.96(4)$ \\
Use of more fertilizers/Pesticides & $4.19(5)$ \\
Irrigation Practices & $4.30(6)$ \\
Growing vegetables in poly house & $4.60(7)$ \\
\hline
\end{tabular}

${ }^{\star}$ Extremely significant $(\mathrm{p}<0.01)$

in cropping patterns and species followed by agroforestry, use of improved seeds, shift to other income generation activities, use of more fertilizers, irrigation practices and growing vegetables in poly house. Non parametric Friedman rank test showed that different respondents ranked the adaptation practices in response to LST change differently which is statistically extremely significant $\left(\chi^{2}=27.646\right.$, $\mathrm{p}<0.01$ ) in Phewa watershed.

\section{Discussion}

\section{LULC dynamics in Phewa watershed}

Regmi and Saha (2015) have found that dense forests have decreased during the study periods 2000, 2005 and 2010 and the prediction of 2015 and 2020. They have also observed that medium to fairly dense forests and open forests have increased during these study periods and predicted periods. The increase in forest area has been aided by the proper management of the forest through introduction of community forest programs, Forest Act and Forest Regulation in the middle mountains (Niraula et al. 2013), reduction in the dependency of the fuelwood (Pandey et al. 2016), decreasing dependency on forest for manure and grass and use of alternative sources of energy such as Liquid Petroleum Gas, solar energy and electricity (Balla et al. 2014). Expansion of private forests in the abandoned cultivated land (KC et al. 2017) has increased forest area. Population growth and expansion of municipal boundaries are the primary factors for the rapid increase of built-up areas (Rai et al. 2020). Rapid urbanization occurs due to drivers like economic opportunities, population growth, migration, public service accessibility, globalization, tourism, plans and policies, land market and political factors (Rimal et al. 2015). Adhikari et al. (2016) revealed that there is a decrease in cultivated land with the increase of settlement due to increase of urban expansion and development. There is increasing migration trend of youth to towns and cities due to lack of employment opportunities and political stability which ultimately led abandonment of cultivated land in mid hill of Nepal (KC et al. 2017). Increased costs of production (Jaquet et al. 2016) have created a favorable environment for the natural appearance of vegetation in abandoned agricultural land. There is decreasing trend in agricultural land in Phewa watershed (MOFE 2018; Regmi and Saha 2015). Multiple hazards such as avalanches, debris flow, soil erosion and sinkholes due to unpredicted precipitation finally contribute to increase in barren area (Jaquet et al. 2015). Increasing abandonment of agricultural land has raised vulnerability towards various geomorphic changes leading towards the formation of barren land (Khanal and Watanabe 2006). Haphazard 
rural road constructions and developmental activities accelerate soil erosion which facilitates the transport of sand and gravel into the lake (MOFE 2018; Regmi and Saha 2015). Heyojoo and Takhachhe (2014) have explained that sediment deposition in the lake is induced by human activities like haphazard road construction and unsuitable land use practices in both upstream and downstream areas in the watershed.

\section{LST analysis of each class in Phewa watershed}

The urban temperatures have $2-5^{\circ} \mathrm{C}$ higher than those in rural surroundings (Ackerman 1985).Urban areas exhibit high mean LST than other LULC classes (Nzoiwu et al. 2017). Urban areas add more roads, buildings, industries and population so temperatures in downstream areas become much higher than temperatures in rural surroundings resulting Urban Heat Island (UHI) phenomenon (Voogt 2004). Increase in impermeable hard and dark surfaces such as stone, metal, asphalt and concrete building materials increase LST by low reflection and high absorption of solar radiation (Buyadi et al. 2013) and do not allow moisture seepage into the soil (Deng et al. 2018). Urban areas suggests greater construction of building areas which hinders heat dissipation by wind resulting in high LST (Mushore et al. 2017). Green spaces can reduce UHI intensity (Guha et al. 2018). Vegetation cools temperature mainly through shading and evapotranspiration processes which absorbs heat energy and releases water vapor and thus reducing the temperature (Zhang et al. 2014). Water bodies can reduce UHI intensity (Guha et al. 2018). The temperature of water bodies is usually lower than other kinds of land uses (Zhang and Huang 2015). Water bodies contribute to mitigate high temperature and enhancement of the cooling effects (Rasul et al. 2017) and helps to control LST (Chen and Zhang 2017). Agricultural land consists of sparse vegetation and exposed bare soil which is less effective in mitigating urban warming effect than forest (Estoque et al. 2017). Mushore et al. (2017) found that cultivated land act as a heat source as they absorb and release large amounts of heat due to negligible evaporation. Du et al. (2009) found that higher temperature is found on barren land because it comprised of areas where ongoing development was taking place and they had no vegetation cover. Open barren land has low evapotranspiration as compared to vegetated land (Sinha et al. 2015).

\section{Adaptation practices in response to LST change}

Soil and water management, adjustments to the timing of farm operations and crop and varietal adjustment by farming households are the major adaptation strategies at local level (Dahal et al. 2018). Karki et al. (2020) revealed that adaptation strategies include crop and varietal adjustments, fertilizer management, farm operations time management, adoption of technologies, diversification of income sources and agriculture practices, soil and water management, migration, access to financial resources and risk reduction measures. Efficient water technology, use of farmland in cash crops, vegetables and fruit production, growing vegetables in poly houses, livelihood diversification, changing cropping patterns and species, compost making and farm yard manure improvement are major adaptation practices in response to climate change (Adhikari et al. 2018).

\section{Conclusion}

LST in relation to LULC dynamics and associated adaptation practices in response to LST change in Phewa watershed of western Nepal was analyzed based on geospatial tools and social survey techniques. Use of temporal satellite data are very useful, time saving and cost effective for the preparation of LULC maps, change analysis and LST assessment. There was a drastic change in LULC in Phewa watershed during the study periods. Agricultural land and urban areas were found to have increased 
by $6.6 \%$ and $0.32 \%$ respectively while forest area, barren land and water bodies were found to have decreased by $1.88 \%, 4.41 \%$ and $0.63 \%$, respectively between 1990 and 2007. Forest area, urban areas and barren land had increased by $5.54 \%, 1.32 \%$ and $1.48 \%$, respectively while agricultural land and water bodies were observed to have decreased by $8.2 \%$ and $0.13 \%$, respectively, between 2007 and 2020 . The analysis of change process using Landsat imageries showed compromise among various LULC classes. The mean LST was in increasing trend during study periods for March-April and January-December. The highest and lowest mean LST was found for urban areas and water bodies during study periods for MarchApril and January-December. LULCC due to rapid urbanization was considered the major contributor to urban climatic warming which created the major spatiotemporal variation in LST particularly due to urban growth, construction of new built up and pollution expansion that could be attributed to settlement expansion resulting in a large amount of waste heat in turn affecting the surface energy budget. There is overall increasing trend of mean LST in tropical zone, sub-tropical and temperate zone during study periods for March-April and January-December. The highest rank to adaptation practices was for change in cropping patterns and species followed by agroforestry, use of improved seeds, shift to other income generation activities, use of more fertilizers, irrigation practices and growing vegetables in poly house which was statistically significant. The above findings recommend the establishment of measures that can mitigate strong effect of increasing LST and may help in promulgating sustainable urban land use policies for avoiding the effect of urban heat island. So, this study provides scientific insights for policy makers and urban planners in improving urban planning and management.

\section{Acknowledgements}

We would like to acknowledge MoFESC of Gandaki Province for providing financial support to accomplish this study. We are grateful to all reviewers and editors for their valuable suggestions during the finalization of the paper. We are thankful to Milan Buddha, Bibek Subedi, Sundar Dhungana, Santosh Bhattarai and Bhuwan Singh Bist for their help and encouragement. We also appreciate the respondents of study area for their participation during our field visit. 


\section{References}

Ackerman, B. (1985). Temporal march of the Chicago heat island. Journal of Climate and Applied Meteorology, 24(6), 547-554..https://doi. org/10.1175/1520-0450(1985)024<0547:TM $\mathrm{OTCH}>2.0 . \mathrm{CO} ; 2$.

Adhikari, S., Baral, H., \& Nitschke, C. (2018). Adaptation to climate change in Panchase Mountain ecological regions of Nepal. Environments, 5(3), 42. https://doi. org/10.3390/environments5030042.

Adhikari, S., Shrestha, S. M., Singh, R., Upadhaya, S., \& Stapp, J. R. (2016). Land use change at subwatershed level. Hydrol Current Res, 7(256), 2. doi: 10.4172/2157-7587.1000256.

Arnfield, A. J. (2003). Two decades of urban climate research: a review of turbulence, exchanges of energy and water, and the urban heat island. International Journal of Climatology: a Journal of the Royal Meteorological Society, 23(1), 1-26. https://doi.org/10.1002/joc.859.

Balla, M. K., Tiwari, K. R., Kafle, G., Gautam, S., Thapa, S., \& Basnet, B. (2014). Farmer's dependency on forests for nutrients transfer to farmlands in mid-hills and high mountain regions in Nepal (case studies in Hemja, Kaski, Lete and Kunjo, Mustang district). International Journal of Biodiversity and Conservation, 6(3), 222-229. https://doi. org/10.5897/IJBC2013.0670.

Bhandari, K. P., \& Darnsawasdi, R. (2014). Sensitivity Analysis of Soil Erosion on Impacts of Land use Land Cover Change in Phewa Watershed. International Journal of Current Engineering and Technology, 4(3), 1-8.

Bhatta, K. P., Bhattarai, S., \& Aryal, A. (2018). Community based anti-poaching operation: Effective model for wildlife conservation in Nepal. Poult. Fish. Wildl. Sci, 6(2). doi:10.4172/2375-446X.1000195.

Buyadi, S. N. A., Mohd, W. M. N. W., \& Misni, A. (2013). Impact of land use changes on the surface temperature distribution of area surrounding the National Botanic Garden, Shah Alam. Procedia-Social and Behavioral Sciences, 101, 516-525. https:// doi.org/10.1016/j.sbspro.2013.07.225.

Chen, X., \& Zhang, Y. (2017). Impacts of urban surface characteristics on spatiotemporal pattern of land surface temperature in Kunming of China. Sustainable Cities and Society, 32, 8799. doi:10.1016/j.scs.2017.03.013.

Dahal, B. M., Raut, N., Gurung, S., Sharma, C. M.,
Kayastha, R., Shrestha, A., \& Gautam, B. (2018). Changing trends in cultivation practices and adoption of climate adaptive farming in Eastern Nepal. Sustainable Agriculture Research, 7(526-2020-483), 5262. doi:10.5539/sar.v7n3p52.

Deng, Y., Wang, S., Bai, X., Tian, Y., Wu, L., Xiao, J., \& Qian, Q. (2018). Relationship among land surface temperature and LUCC, NDVI in typical karst area. Scientific reports, $8(1)$, 1-12. https://doi.org/10.1038/s41598-01719088-x.

Dousset, B. \& Gourmelon, F. (2003) Satellite multisensor data analysis of urban surface temperatures and land cover. Journal of Photogrammetry and Remote Sensing. 58. 4354. doi: 10.1016/S0924-2716(03)00016-9.

Du, M., Wang, Q., \& Cai, G. (2009). Temporal and spatial variations of urban heat island effect in Beijing using ASTER and TM data. In 2009 Joint Urban Remote Sensing Event (pp. 1-5). IEEE.

Estoque, R. C., Murayama, Y., \& Myint, S. W. (2017). Effects of landscape composition and pattern on land surface temperature: An urban heat island study in the megacities of Southeast Asia. Science of the Total Environment, 577, 349-359. https://doi.org/10.1016/j. scitotenv.2016.10.195.

FAO. (2000) Global Forest Resources Assessment Food and Agriculture Organization of United Nations, Rome.

Guha, S., Govil, H., Dey, A., \& Gill, N. (2018). Analytical study of land surface temperature with NDVI and NDBI using Landsat 8 OLI and TIRS data in Florence and Naples city, Italy. European Journal of Remote Sensing, 51(1), 667-678. https://doi.org/10.1080/2279 7254.2018.1474494.

Hamad, R., Kolo, K., \& Balzter, H. (2018). Land cover changes induced by demining operations in Halgurd-Sakran National Park in the Kurdistan Region of Iraq. Sustainability, 10(7), 2422. https://doi.org/10.3390/ su10072422.

Haylemariyam, M. B. (2018). Detection of land surface temperature in relation to land use land cover change: Dire Dawa City, Ethiopia. Journal of Remote Sensing and GIS, 7(3).245. doi:10.4172/2469-4134.1000245.

Heyojoo, B. P., \& Takhachhe, P. (2014). An assessment of lake area shrinkage through geospatial approach: case study of Phewa Lake of Kaski district, Nepal. International Journal 
of Multidisciplinary and Current Research, 2, 725-728.

IPCC. (2001). Climate Change 2001: Impacts, Adaptations and Mitigation of Climate Change. Contribution of the Working Group II to the Third Assessment Report of the Intergovernmental Panel on Climate Change.

IPCC. (2007). Climate change 2001: Impacts, Adaptation and Vulnerability. Contribution of Working Group II to fourth assessment report of Intergovernmental Panel on Climate Change.

Jaquet, S., Shrestha, G., Kohler, T., \& Schwilch, G. (2016). The effects of migration on livelihoods, land management, and vulnerability to natural disasters in the Harpan watershed in western Nepal. Mountain Research and Development, 36(4), 494-505.

doi:10.1659/MRD-JOURNAL-D-16-00034.1.

Jaquet, S., Schwilch, G., Hartung-Hofmann, F., Adhikari, A., Sudmeier-Rieux, K., Shrestha, G. \& Kohler, T. (2015). Does outmigration lead to land degradation? Labour shortage and land management in a western Nepal watershed. Applied geography, 62, 157-170. https://doi.org/10.1016/j. apgeog.2015.04.013.

Karki, S., Burton, P., \& Mackey, B. (2020). Climate change adaptation by subsistence and smallholder farmers: Insights from three agro-ecological regions of Nepal. Cogent Social Sciences, 6(1), 1720555. https://doi.or $\mathrm{g} / 10.1080 / 23311886.2020 .1720555$.

K, C., Bhawana, Wang, T., \& Gentle, P. (2017). Internal migration and land use and land cover changes in the middle mountains of Nepal. Mountain Research and Development, 37(4), 446-455. doi:10.1659/MRDJOURNAL-D-17-00027.1.

Khanal, N. R., \& Watanabe, T. (2006). Abandonment of agricultural land and its consequences. Mountain Research and Development, 26(1), 32-40.doi:10.1659/02764741(2006)026[0032:AOALAI]2.0.CO;2.

Lillesand, T.M., Kiefer, R.W. \& Chipman, J.W. (2004). Remote Sensing and Image Interpretation. John Wiley \& Sons, New York, USA. 31.

Li, Z. L., Tang, B. H., Wu, H., Ren, H., Yan, G., Wan, Z., \& Sobrino, J. A. (2013). Satellite-derived land surface temperature: Current status and perspectives. Remote sensing of environment, 131, 14-37. https://doi.org/10.1016/j. rse.2012.12.008.
Mallick, J., Kant, Y., \& Bharath, B. D. (2008). Estimation of land surface temperature over Delhi using Landsat-7 ETM+. J. Ind. Geophys. Union, 12(3), 131-140.

Mathew, A., Sreekumar, S., Khandelwal, S., Kaul, N., \& Kumar, R. (2016). Prediction of surface temperatures for the assessment of urban heat island effect over Ahmedabad city using linear time series model. Energy and Buildings, 128, 605-616. https://doi. org/10.1016/j.enbuild.2016.07.004.

McGray, H., Hammill, A., Bradley, R., Schipper, L., \& Parry, J. E. (2007). Weathering the storm: options for framing adaptation and development (p. 57). Washington, DC: World Resources Institute.

MOE. (2010). National Adaption Programme of Action (NAPA) to Climate Change. Kathmandu: Government of Nepal, Ministry of Environment (MoE).

MoFE, (2018). Integrated Lake Basin Management Plan of Lake Cluster of Pokhara Valley, Nepal (2018-2023). Ministry of Forests and Environment, Kathmandu, Nepal.

Mushore, T. D., Odindi, J., Dube, T., \& Mutanga, O. (2017). Prediction of future urban surface temperatures using medium resolution satellite data in Harare metropolitan city, Zimbabwe. Building and Environment, 122, 397-410. https://doi.org/10.1016/j. buildenv.2017.06.033.

Nayana, S.R., Ajay D. N. \& Bharti G. (2016). Analysis of Land Use / Land Cover Changes Using Remote Sensing and GIS Techniques in Parbhani City, Maharashtra, India. International Journal of Advanced Remote Sensing and GIS, 5(4), 1702-1708. doi: 10.23953/cloud.ijarsg.54.

Niraula, R. R., Gilani H., Pokharel, B. K. \& Qamer. F. M. (2013). Measuring impacts of community forestry program through repeat photography and satellite remote sensing in the Dolakha district of Nepal. Journal of environmental management. 126: 20-29. doi:10.1016/j.jenvman.2013.04.006.

Nzoiwu, C. Agulue, E. Mbah, S. \& Igboanugo, C. (2017) Impact of Land Use/Land Cover Change on Surface Temperature Condition of Awka Town, Nigeria. Journal of Geographic Information System, 9, 763-776. doi: 10.4236/ jgis.2017.96047.

Osborne, P. E., \& Alvares S. T. (2019). Quantifying how landscape composition and configuration affect urban land surface 
temperatures using machine learning and neutral landscapes. Computers, Environment and Urban Systems, 76, 80-90. doi: 10.1016/j. compenvurbsys.2019.04.003.

Pal, S., \& Ziaul, S. (2017). Detection of land use and land cover change and land surface temperature in English Bazar urban center. Egypt J Remote Sens Space Sci 20 (1): 125-145. https://doi.org/10.1016/j. ejrs.2016.11.003.

Pandey, D., Heyojoo, B. P., \& Shahi, H. (2016). Drivers and dynamics of land use land cover in Ambung VDC of Tehrathum district, Nepal. Banko Janakari, 26(1), 90-96. https:// doi.org/10.3126/banko.v26i1.15508.

Paudyal, K., Baral, H., Putzel, L., Bhandari, S., \& Keenan, R. J. (2017). Change in land use and ecosystem services delivery from communitybased forest landscape restoration in the Phewa Lake watershed, Nepal. International Forestry Review, 19(4), 88-101. https://doi. org/10.1505/146554817822330524.

Rai, R., Yili, Z., Paudel, B., Khanal, N. R., \& Acharya, B. K. (2020). Satellite Image-based Monitoring of Urban Land Use Change and Assessing the Driving Factors in Pokhara and Bharatpur Metropolitan Cities, Gandaki Basin, Nepal. Journal of Resources and Ecology, 11(1), 8799.doi:10.5814/j.issn.1674-764x.2020.01.009. Rajendran, P., \& Mani, K. (2015). Estimation of spatial variability of land surface temperature using Landsat 8 imagery. International Journal of Engineering and Science, 11(4), 19-23.

Rasul, A., Balzter, H., Smith, C., Remedios, J., Adamu, B., Sobrino, J. A,. \& Weng, Q. (2017). $A$ review on remote sensing of urban heat and cool islands. Land, 6(2), 38. https://doi. org/10.3390/land6020038.

Regmi, R. R., \& Saha, S. K. (2015). Impact assessment of land use land cover change on soil erosion status in Phewa Lake watershed of Nepal. International Journal of Current Engineering and Technology, 5(3), 1708-1717.

Regmi, S. R., Thapa, M. S., \& Regmi, R. R. (2020). Drivers and Dynamics of Land Use Land Cover in Phewa Watershed, Kaski, Nepal. Journal of Forest and Natural Resource Management, 2(1), 19-36. https://doi. org/10.3126/jfnrm.v2i1.40218.

Rimal, B., Baral, H., Stork, N. E., Paudyal, K., \& Rijal, S. (2015). Growing city and rapid land use transition: Assessing multiple hazards and risks in the Pokhara Valley, Nepal. Land, 4(4), 957-978. https://doi.org/10.3390/ land4040957.

Roy, S., Farzana, K., Papia, M., \& Hasan, M. (2015). Monitoring and prediction of land use/ land cover change using the integration of Markov chain model and cellular automation in the Southeastern Tertiary Hilly Area of Bangladesh. Int. J. Sci. Basic Appl. Res, 24, 125-148.

Sinha, S., Sharma, L. K., \& Nathawat, M. S. (2015). Improved land-use/land-cover classification of semi-arid deciduous forest landscape using thermal remote sensing. The Egyptian Journal of Remote Sensing and Space Science, 18(2), 217-233. https://doi.org/10.1016/j. ejrs.2015.09.005.

Smith, J. B., Schneider, S. H., Oppenheimer, M., Yohe, G. W., Hare, W., Mastrandrea, M. D., \& van Ypersele, J. P. (2009). Assessing dangerous climate change through an update of the Intergovernmental Panel on Climate Change (IPCC) "reasons for concern". Proceedings of the national Academy of Sciences, 106(11), 4133-4137. https://doi.org/10.1073/ pnas.0812355106.

Tran, D. X., Pla, F., Latorre-Carmona, P., Myint, S. W., Caetano, M., \& Kieu, H. V. (2017). Characterizing the relationship between land use land cover change and land surface temperature. ISPRS Journal of Photogrammetry and Remote Sensing, 124, 119-132. https://doi.org/10.1016/j. isprsjprs.2017.01.001.

USGS. (2014). Landsat 8 reprocessing to begin February 3, 2014. https:// landsat.usgs.gov/ landsat-8-18-operational-land-imager-oliand-thermal-infrared-sensor-tirs.

Vittek, M., Brink, A., Donnay, F., Simonetti, D., \& Desclée, B. (2014). Land cover change monitoring using Landsat MSS/TM satellite image data over West Africa between 1975 and 1990. Remote sensing, 6(1), 658-676. https://doi.org/10.3390/rs6010658.

Voogt, J. A. (2004). Urban Heat Island: Hotter Cities. Action Bioscience, North Port. FL, USA, Available online: http://www. actionbioscience. org/environment/voogt. html.

Voogt, J. A., \& Oke, T. R. (2003). Thermal remote sensing of urban climates. Remote sensing of environment, 86(3), 370-384. https:/doi. org/10.1016/S0034-4257(03)00079-8.

Wang, S., Ma, Q., Ding, H., \& Liang, H. (2018). Detection of urban expansion and land surface temperature change using multi- 
temporal landsat images. Resources, Conservation and Recycling, 128, 526-534.. doi: 10.1016/j.resconrec.2016.05.011.

Xian, G., \& Crane, M. (2005). Evaluation of urbanization influences on urban climate with remote sensing and climate observations. In Proceedings of the ISPRS joint conference 3rd International Symposium Remote Sensing and Data Fusion Over Urban Areas (URBAN 2005) 5th International Symposium Remote Sensing of Urban Areas (URS 2005) Tempe, $A Z$ (pp. 14-16).

Xu, Z., Jiang, Y., \& Zhou, G. (2015). Response and adaptation of photosynthesis, respiration, and antioxidant systems to elevated $\mathrm{CO} 2$ with environmental stress in plants. Frontiers in plant science, 6, 701. https://doi.org/10.3389/ fpls.2015.00701.

Yu, X., Guo, X., \& Wu, Z. (2014). Land surface temperature retrieval from Landsat 8 TIRS-
Comparison between radiative transfer equation-based method, split window algorithm and single channel method. Remote sensing, 6(10), 9829-9852. https:// doi.org/10.3390/rs6109829.

Zhang, W., \& Huang, B. (2015). Land use optimization for a rapidly urbanizing city with regard to local climate change: Shenzhen as a case study. Journal of Urban Planning and Development, 141(1), 05014007. doi:10.1061/ (ASCE)UP.1943-5444.0000200.

Zhang, B., Gao, J. X., \& Yang, Y. (2014). The cooling effect of urban green spaces as a contribution to energy-saving and emission-reduction: A case study in Beijing, China. Building and environment, 76, 37-43. https://doi. org/10.1016/j.buildenv.2014.03.003. 